\title{
Nonylphenol and Nonylphenol Ethoxylates in River Water, Drinking Water, and Fish Tissues in the Area of Chongqing, China
}

\author{
Bing Shao, ${ }^{1,2}$ Jianying Hu, ${ }^{1}$ Min Yang, ${ }^{2}$ Wei An, ${ }^{1}$ Shu Tao ${ }^{1}$ \\ ${ }^{1}$ College of Environmental Science, Peking University, 100871, Beijing, China \\ ${ }^{2}$ State Key Lab of Environmental Aquatic Chemistry, Research Center for Eco-Environmental Sciences, Chinese Academy of Sciences, \\ 100085, Beijing, China
}

Received: 7 January 2004/Accepted: 23 June 2004

\begin{abstract}
Little attention has been paid to the estrogenic-like compounds, such as 4-nonylphenol (4-NP) and its potential precursor nonylphenol ethoxylates (NPEOs), in China although its usage is huge. Water samples and corresponding drinking water samples were seasonally collected at five sites of each of the two main rivers in Chongqing Area. Individual nonylphenol ethoxylates (NPEOs) and 4-NP in the Changjiang River and Jialingjiang River were detected by normal-phase liquid chromatography electrospray ionization mass spectrometry and gas chromatography-mass spectrometry. The results indicated that of the five sampling points in the two rivers, NPEOs were the dominant pollutant in April and December with the similar distribution profile, and total NPEOs with different ethylene oxide lengths were 6.9-97.6 $\mu \mathrm{g} / \mathrm{L}$ in April and 2.5-52.7 $\mu \mathrm{g} / \mathrm{L}$ in December. However, NP was the dominant pollutant in July with a concentration of 1.7-7.3 $\mu \mathrm{g} / \mathrm{L}$. Corresponding drinking water samples derived from river water as source suggested that the conventional water treatment process used in the five waterworks could remove NPEOs from the source water with high removal efficiency (>99\%). The 4-NP removal efficiency, however, varied in a range of $62 \%$ to $95 \%$, leaving a significantly high concentration of NP $(0.1$ to $2.7 \mu \mathrm{g} / \mathrm{L})$ in drinking water in July. Fish samples taken in December 2000 contained 4-NP of $\sim 1.9 \mu \mathrm{g} / \mathrm{g}$ and NPEOs of $0.4-48.3 \mu \mathrm{g} / \mathrm{g}$, with the highest concentration level found in liver.
\end{abstract}

Recent studies have demonstrated that compounds such as short nonylphenol ethoxylates (NPEOs) homologues, carboxylated metabolites and 4-nonylphenol (4-NP) could exert estrogenic effects on aquatic fish, mammals, and birds (White et al. 1994; Sharpe et al. 1995; Jobling et al. 1996; Servos, 1999). In vivo bioassay studies have shown that gestational and lactational exposure of male rats to octylphenol ethoxylates with five-unit EO chains results in reduced testicular size and

Correspondence to: Jian-ying. Hu; email: hujy@urban.pku.edu.cn sperm production (Sharpe et al. 1995). There is increasing evidence that the above intermediates are capable of inducing synthesis of the yolk protein vitellogenin in male rainbow trout (Blackburn and Waldock 1995; Harries et al. 1996). Although these compounds elicit lower estrogenic potency than the natural hormone, the significance of exposure to these biodegradation intermediates should not be neglected, since they are prevalent in the environment.

The occurrence of NPEOs and intermediates in water and sediment in the United States, Europe, and Japan has been well documented (Naylor et al. 1996; Kannan et al., 2003; Ahel et al. 1994; Di Corcia et al. 2000; Maruyama et al. 2000, Thiele et al. 1997). Recently, several studies have examined the residues of 4-NP and NPEOs with short EO units $(\mathrm{n}<6)$ in fish (Rice et al. 2003; Tsuda et al. 2000; Keith et al. 2001; Lye et al. 1999; Ferrara et al. 2001; Kannan et al., 2003). To date, there is no documented evidence of the existence of NPEOs with more than 5 units in fish.

The annual output of alkylphenol ethoxylates (most of which are NPEOs) in China is estimated to be about 50,000 tons (Huang 1998). In some countries, the above compounds pollute the aquatic environments mainly through the discharging of sewage treatment effluents, with NP2EC and NP1EC usually the dominant products, followed by NP2EO, NP1EO, and 4-NP (Jonkers et al. 2001; Di Corcia et al. 2000); in China, point sources are the dominant contributor of the compounds because of the low sewage treatment ratio (the volume ratio of treated sewage to and the total discharged sewage), which is reported to be less than $35 \%$ in 2002 in China (http://www.cin.gov.cn/ indus/speech/2001072303). Notwithstanding the large annual output of NPEOs, little information is available on the environmental behavior of NPEOs and the related compounds in China. A comprehensive analytical method based on normalphase liquid chromatography electrospray ionization mass spectrometry (NPLC-ESI-MS) has been established in our lab for determination of NPEOs with the whole chain length in the aquatic environment (Shao et al. 2002a). In this paper, we first document the occurrence and seasonal changes of NPEOs and their intermediates in the Changjiang and Jialingjiang rivers in Chongqing City, China. The residual concentrations of these compounds in drinking water and fish were also detected to 


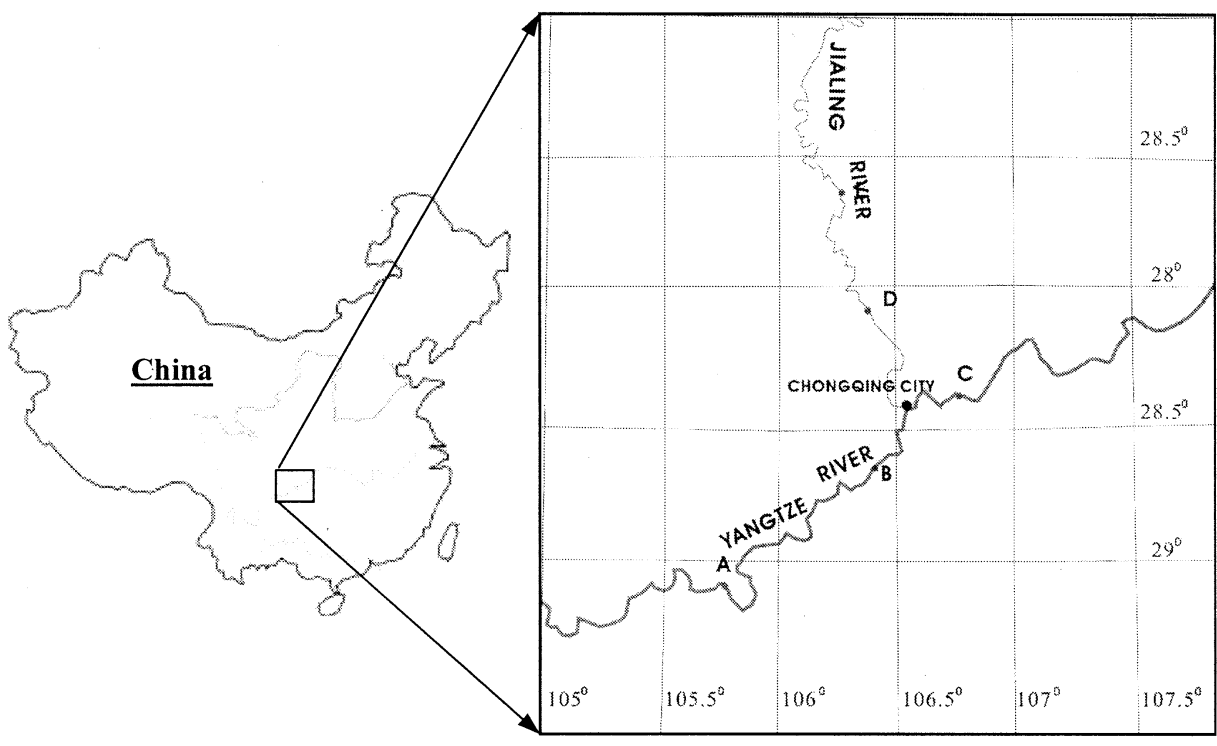

Fig. 1. Distribution of sampling sites provide information on the dietary exposure of humans. Changjiang River, the largest river and most important water resource in China, provides fresh water with a capacity of $10^{12}$ $\mathrm{m}^{3}$ per year. Chongqing City, the most important industrial city upstream of the Changjiang River, affects the water quality of the river to a large extent with its huge population (30 million) and industrial output. Because of this, the information from our research is very important to the policymakers in China to evaluate the risks of this group of chemicals.

\section{Materials and Methods}

\section{Materials}

4-Nonylphenol (technical grade), a mixture of compounds with branched side chains, was purchased from Kanto Chemicals (Tokyo, Japan). Authentic standard nonylphenol mono- (NP1EO), die(NP2EO), and tri- (NP3EO), tetra- (NP4EO), penta- (NP5EO), hexaethoxylates (NP6EO) and mixture standard of NP9EO (a mixture of NPEOs with an average of nine EO units) and NP15EO (a mixture of NPEOs with an average of 15 EO units) were purchased from Hayashi Pure Chemicals (Tokyo, Japan). Standard stocking solutions were prepared in acetonitrile.

Methylene chloride, acetonitrile, and methanol were all highperformance liquid chromatography (HPLC) grade obtained from Fisher Chemicals Co. (Beijing, China). Ultrapure water was made by the Easypure UV compact ultrapure system (Barnstead Internatinal Dubugue, IA) at a resistivity of $18.3 \mathrm{M} \Omega / \mathrm{cm}$. Supleclean ENVI-Carb solid phase extraction cartridges (GCB) and a $6 \times 1.4-\mathrm{cm}$ i.d. polypropylene tube $(500 \mathrm{mg}$ ) were purchased from Supelco (Bellefonte, PA) for sample preparation. All the glassware are rinsed with n-hexane and acetone of pesticide residue grade and then baked in muffle at $400^{\circ} \mathrm{C}$ for $4 \mathrm{~h}$ before use to avoid contamination.

\section{Sample Collection and Preparation}

Chongqing City, one of the most important industrialized cities in China, is surrounded by the Changjiang River and the Jialingjiang River (which eventually flows into the Changiiang River). The two rivers are used as the water source for the Chongqing area. As shown in Figure 1, sites $A$ and $E$ were located upstream of the Changjiang River and sites B and D were downstream of the Jialingjiang River. Site $\mathrm{C}$ was the converging site of the two rivers. Sampling on the five sites was conducted in April 28, July 28, and December 26, 2000, respectively. The corresponding water temperatures were about 12,28 , and $15^{\circ} \mathrm{C}$, respectively. The river samples were taken from the water intake of the respective waterworks, and the samples of drinking water were from the distribution tank of each waterworks. All of the five waterworks use the conventional coagulation/sedimentation/sand filtration process for drinking water production. The samples were collected into precleaned glass bottles and prepared immediately after collection. Otherwise, $1 \%$ of formaldehyde was added to prevent microbial degradation and the samples were stored at $4^{\circ} \mathrm{C}$ in the dark. For further investigation on the possible bioeffect, fish samples (Coreius Guichenoti, Coreius heterodon, Leptobotia elongata, Rhinogobio Typu, Rhinogobio ventralis) and corresponding river water from the two rivers were taken on December 26, 2001. Unfortunately, fish samples from sites A, C, and E were not available in spite of the efforts in sample taking. Sediment samples were not available because the river bottoms are composed of cobblestones and fine-grained sands.

The sample extraction method proposed by Di Corcia et al. (1998, 2000) was used with minor modification. Briefly, water samples (1 L) were filtrated by a $0.45-\mu \mathrm{m}$ glass fiber filter paper (Millipore Co. Bedford, MA, USA). The filter paper was soaked in 100-ml methanol/ water $(50: 50, \mathrm{vol} / \mathrm{vol})$ solution for $2 \mathrm{~h}$, and then ultrasonicated for $30 \mathrm{~min}$. The acquired solution was mixed with filtrate before extraction. A GCB cartridge was conditioned sequentially with $10 \mathrm{ml}$ of methylene chloride/methanol (80:20, vol/vol), $6 \mathrm{ml}$ methanol, and $6 \mathrm{ml}$ water with $\mathrm{pH}=3$. The acidified sample $(\mathrm{pH}=3)$ was passed through a GCB cartridge with a flow rate of $10-15 \mathrm{ml} / \mathrm{min}$, and a $100 \mathrm{ml} 50 \%$ methanol/ water mixture used for washing the reservoirs was also passed through the cartridge. An additional $10 \mathrm{ml}$ of water was applied to wash the walls of the cartridges. The residual water was removed by passing a gentle nitrogen stream through the cartridges for about $10 \mathrm{~min}$. NPEOs were desorbed from the cartridges by $10 \mathrm{ml}$ methylene chloride/methanol $(80: 20, \mathrm{vol} / \mathrm{vol})$. Finally, the residues were dried under a gentle nitrogen stream, and reconstituted with $2 \mathrm{ml}$ of ion reagent, an acetonitrile/water $(95: 5, \mathrm{vol} / \mathrm{vol})$ solution containing $1 \mathrm{mmol} / \mathrm{L}$ sodium acetate.

For fish samples, $0.5 \mathrm{~g}$ each of muscle, liver, and gill (wet weight) were mixed with $15 \mathrm{~g}$ anhydrous sodium sulfate and Soxhlet extracted with a solvent mixture of methanol/methylene chloride (3:7) for $14 \mathrm{~h}$. 
The extract was rotary evaporated to a volume of $1 \mathrm{ml}$ and then transferred to a flask with $4 \times 100 \mathrm{ml}$ water. The solution was rinsed with a GCB SPE cartridge using the same procedure based on Di Corcia's extraction method.

\section{Analysis}

The final extracts were measured using the LC-ESI-MS methods and GC-MS previously described (Shao et al. 2002a, 2002b). NPEOs with $\mathrm{n}>2$ were detected by LC-ESI-MS. A platform ZMD single quadrupole mass spectrometer (Micromass, Manchester, U.K.) was used with a Z-Spray ion source fitted with a pneumatically assisted electrospray probe. NPEOs were detected in the positive mode, typical ion source parameter used as follows: ESI capillary voltage at $3.5 \mathrm{kV}$; extractor voltage at $5 \mathrm{~V}$; source block temperature at $120^{\circ} \mathrm{C}$; desolvation temperature at $180^{\circ} \mathrm{C}$; ion energy at $0.8 \mathrm{~V}$; multiplier voltage at $650 \mathrm{~V}$; nitrogen was used as desolvation gas with flow between 270 and $350 \mathrm{l} / \mathrm{h}$ and cone gas at the flow $70-100 \mathrm{l} / \mathrm{h}$; the cone voltage ramped from 25 to $70 \mathrm{~V}$ with the full scan mass ranged from 280 to 1500 with a scan time of $1.2 \mathrm{~s}$. Masslynx 3.4 workstation software (Waters Corp; Milford, MA). was used for data processing.

The qualitative identification of target compounds was done in full-scan mode by matching time and the mass spectrum with standards. Quantitative analysis was performed using selected ion monitoring in order to achieve maximum sensitivity. A series of five standard solutions were prepared by diluting the standard stock solution. For NPEOs with $\mathrm{n}>6$ without authentic standards, the concentration in the environmental samples was determined by external calibration using NP9EO as a mixture standard. The composition of the environmental samples was determined by analyzing the molar distributions of individual NPEOs in NP9EO or NP15EO and by using HPLC-UV at 277-nm UV absorbance, assuming that each homologue had the same molar adsorption coefficient as described in our previous paper (Shao et al., 2002a). For NPEOs with $\mathrm{n}<6$, pure standard compounds were used to find the calibration curve.

4-NP, NP1EO, NP2EO were measured with GC-MS for their low sensitivities upon using LC-ESI-MS. The specific method was described in a previous report (Shao et al. 2000b). Briefly, operation was performed on a GC-MS (5890SeriesII GC, 5971 MSD, HewlettPacker, USA) with a HP-5-MS column $(0.25-\mathrm{mm}$ i.d. $\times 30 \mathrm{~m}$ in length, $0.25 \mu \mathrm{m})$. Injection port and detector interface temperatures were $230^{\circ} \mathrm{C}$ and $280^{\circ} \mathrm{C}$, respectively. Carrier gas (helium) linear velocity was held constant at $40 \mathrm{~cm} / \mathrm{s}$. The electron energy and electron multiplier voltage were $70 \mathrm{eV}$ and $2000 \mathrm{~V}$, respectively. The injector was carried out in splitless mode with $2-\mu l$ injection volume. The initial oven temperature was $50^{\circ} \mathrm{C}$ and ramped at $20^{\circ} \mathrm{C} / \mathrm{min}$ to $200^{\circ} \mathrm{C}$ with 5-min hold time, and then ramped at $5^{\circ} \mathrm{C} / \mathrm{min}$ to $260^{\circ} \mathrm{C}$.

Absolute detection limits were in the low nanogram per liter range. The performance of SPE was estimated using spiking samples of all oligomers with recoveries ranging from $92 \%$ to $117 \%$ and a relative standard deviation of $2 \%-20 \%$. The detection limits for water samples were estimated to be $10,20,50,2$, and $1 \mathrm{ng} / \mathrm{L}$ for 4-NP, NP1EO, NP2EO, NP3EO, and NPEOs ( $>$ 3), respectively, and 5.0, 20.0, $30.0,5.0$, and $2.0 \mathrm{ng} / \mathrm{g}$ (wet weight) for fish samples.

\section{Results and Discussion}

\section{Concentration Levels of 4-NP and NPEOs in River Samples}

Figure 2 shows the distribution patterns of NPEOs and 4-NP in samples of site A located on the Changjiang River taken on
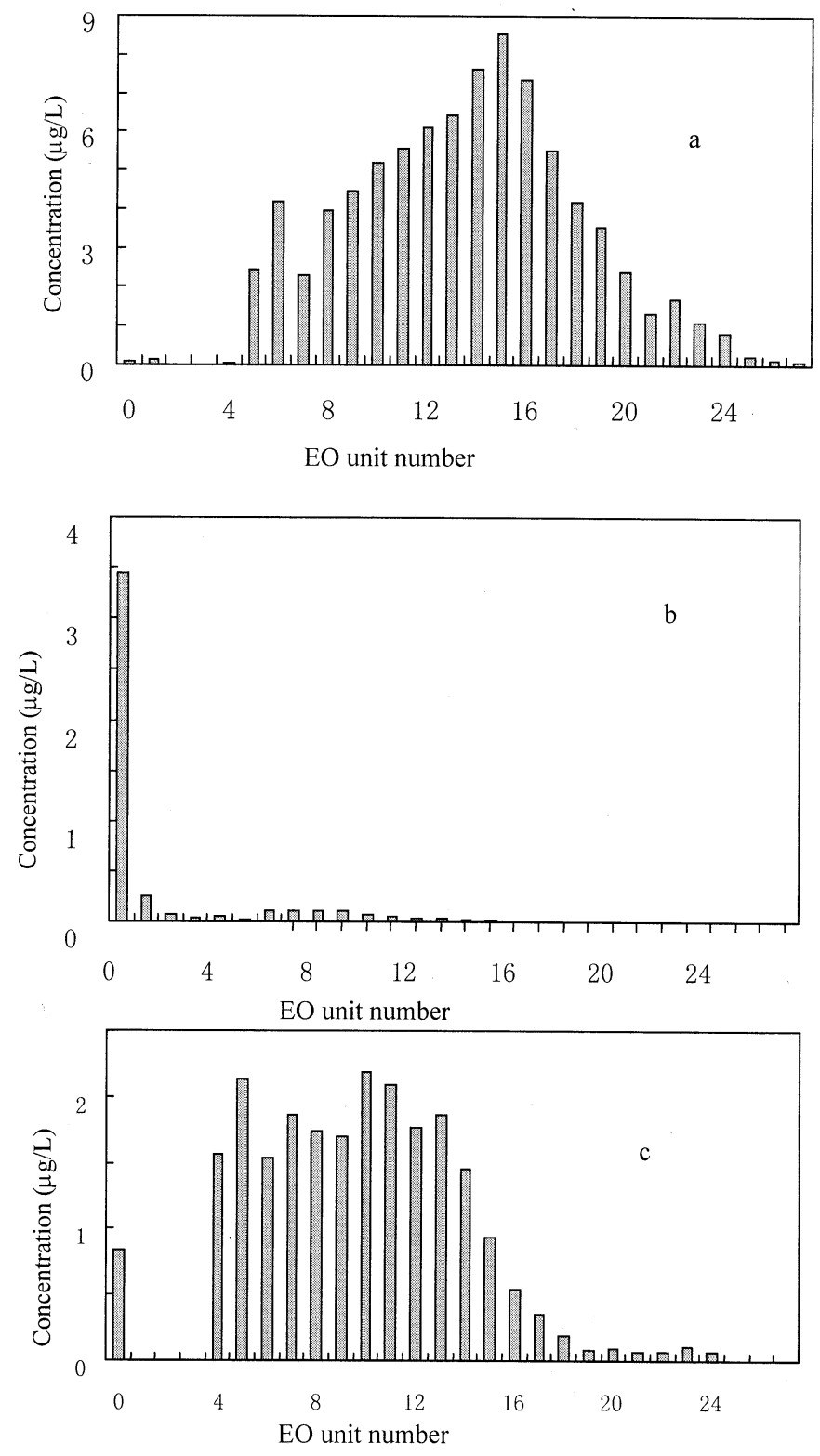

Fig. 2. Distribution of 4-nonylphenol and nonylphenol ethoxylates in river samples of site A. (a) April 2000; (b) July 2000; (c) December 2000.

April 28, July 28, and December 26, 2000. NPEOs with various EO lengths and 4-NP were detected in all samples. In the sample taken April 28 and December 26, the peaks of the NPEOs showed a pattern similar to that of standard NPEOs samples, and NP5EO and NP24EO were the main components. The fact that the 4-NP, NP1EO, and NP2EO were detected in very low levels in samples taken on April 28 and December 26 suggested that NPEOs were not subjected to significant biodegradation under the prevailing environmental conditions (water temperature, $10-15^{\circ} \mathrm{C}$ ). The sample taken from the same site on July 28 , however, showed a very different distribution pattern. 4-NP and NP1EO became the dominating species, indicating that NPEOs degraded rapidly under these conditions (water temperature, $28^{\circ} \mathrm{C}$ ). This seasonal change of 
Table 1. Concentrations of 4-NP and NPEOs in river water and corresponding drinking water $(\mu \mathrm{g} / \mathrm{L})$

\begin{tabular}{|c|c|c|c|c|c|c|c|c|c|c|c|c|c|c|c|}
\hline & \multicolumn{5}{|l|}{ April } & \multicolumn{5}{|c|}{ July } & \multicolumn{5}{|c|}{ December } \\
\hline & $\mathrm{A}$ & B & $\mathrm{C}$ & $\mathrm{D}$ & $\mathrm{E}$ & A & B & $\mathrm{C}$ & $\mathrm{D}$ & $\mathrm{E}$ & A & $\mathrm{B}$ & $\mathrm{C}$ & $\mathrm{D}$ & $\mathrm{E}$ \\
\hline 4-NP (river water) & 0.1 & 0.3 & 0.4 & 1.3 & 0.4 & 3.5 & 7.3 & 2.9 & 3.1 & 1.7 & 0.6 & 2.1 & 0.6 & 3.8 & 1.3 \\
\hline \multirow[t]{2}{*}{ NPEOs(river water) } & 84.9 & 88.9 & 97.6 & 77.2 & 6.9 & 1.1 & 2.6 & 1.3 & 1.0 & 2.1 & 35.2 & 6.6 & 52.7 & 36.6 & 2.5 \\
\hline & A & B & $\mathrm{C}$ & $\mathrm{D}$ & $\mathrm{E}$ & A & $\mathrm{B}$ & $\mathrm{C}$ & $\mathrm{D}$ & $\mathrm{E}$ & A & $\mathrm{B}$ & $\mathrm{C}$ & $\mathrm{D}$ & $\mathrm{E}$ \\
\hline 4-NP (drinking water) & $\mathrm{ND}^{*}$ & 0.05 & 0.01 & ND & 0.06 & 0.2 & 2.7 & 0.7 & 0.9 & 0.1 & ND & 0.2 & 0.01 & 0.02 & 0.02 \\
\hline NPEOs(drinking water) & 0.3 & 0.2 & 0.1 & 0.2 & 0.3 & 0.1 & 0.3 & ND & ND & ND & 0.2 & 0.1 & 0.3 & 0.2 & 0.2 \\
\hline
\end{tabular}

ND - not deteced, 4-NP, 4-nonylphenol; NPEOs, nonylphenol ethoxylates.

NPEOs in river water is consistent with that found in three main rivers in Tokyo, Japan (Maruyama et al. 2000).

NPEOs and 4-NP for each sampling site detected in the river samples are summarized in Table 1. In sites A to D, NPEOs, the prevailing species, in the samples in April were as high as 97.6 $\mu \mathrm{g} / \mathrm{L}$, much higher than those reported in other countries (Maruyama et al. 2000; Blackburn et al. 1995). 4-NP, however, became the dominating species in July, and the concentration level ranged from 1.55 to $7.33 \mu \mathrm{g} / \mathrm{L}$.It is clear that water temperature was an important factor affecting the fate of NPEOs.

Site E was in the upper stream of the Jialingjiang River. From the fact that the NPEOs at site E in April and December were about one-tenth that of sample at site $D$, it is easy to speculate that the main pollution sources were located between sites $\mathrm{E}$ and $\mathrm{D}$. Due to the low sewage treatment ratio (in Chongqing area, it is estimated to be no more than $10 \%$ at the time) (http://www.cqpa.gov.cn/lxryzl/3/info-20020611-2.htm), most of industrial wastewater was discharged into the rivers without biological treatment.

On the other hand, for the samples from the Changjiang River in April, the NPEOs and 4-NP at site A were $84.9 \mu \mathrm{g} / \mathrm{L}$ and $0.1 \mu \mathrm{g} / \mathrm{L}$, respectively, which were similar to those at site B $(88.9 \mu \mathrm{g} / \mathrm{L}$ and $0.30 \mu \mathrm{g} / \mathrm{L}$, respectively). Moreover, in December, the NPEOs and 4-NP at site A were $35.2 \mu \mathrm{g} / \mathrm{L}$ and $0.6 \mu \mathrm{g} / \mathrm{L}$, about fourfold of the concentration at site B with 6.7 $\mu \mathrm{g} / \mathrm{L}$ NPEOs and $2.1 \mu \mathrm{g} / \mathrm{L}$ 4-NP. It is possible that the main sources were located upstream of site A.

As for the results in July, the NPEOs and 4-NP at site A were $1.1 \mu \mathrm{g} / \mathrm{L}$ and $3.5 \mu \mathrm{g} / \mathrm{L}$, which was about half of that at site B (NPEOs, $2.6 \mu \mathrm{g} / \mathrm{L}$; 4-NP, $7.3 \mu \mathrm{g} / \mathrm{L}$ ). This phenomenon can be explained by the gradual biodegradation during transformation and discharging between $\mathrm{A}$ and $\mathrm{B}$.

In addition, the highest concentrations of NPEOs in both April and December were found at site $\mathrm{C}$, located at the convergence of the two rivers, which is probably due to the discharging of some industrial wastewater near this site where many workshops are distributed. The surfactants discharged into the two rivers seemed to be different. The highest individual NPEO concentration in the Changjiang River was attributed to NP15EO, while NP9EO and NP10EO predominated in the Jialingjiang River.

\section{Concentration Levels of 4-NP and NPEOs in Drinking Water}

Figure 3 shows the distribution of NPEOs in drinking water taken from distribution tanks at site A of the Changjiang River.

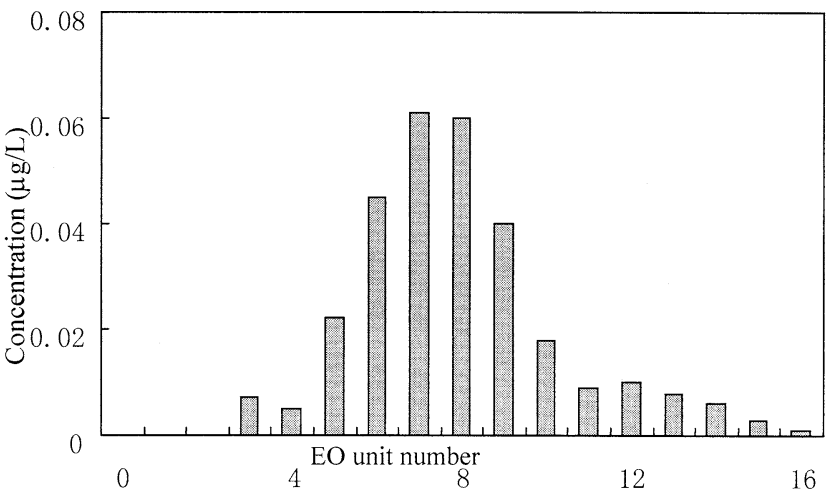

Fig. 3. Distribution of 4-nonylphenol and nonylphenol ethoxylates in the drinking water of site A taken in April 2000

Compared with those in raw water, the most abundant NPEOs species shifted from NP15EO to NP8EO, demonstrating that NPEOs with longer EO units are more easily removed by the water treatment process.

As described in the experimental section, the five sampling sites of the two rivers correspond to the water intakes of the five waterworks, which use the conventional process including coagulation with polychloride aluminum, sedimentation, sand filtration and chlorination. Table 1 lists the concentrations of 4-NP and NPEOs in all the drinking water samples. It is clear that NPEOs could be removed with an efficiency as high as $95 \%$ to $99 \%$ for samples in April and December. In spite of the high concentrations of NPEOs in some source water samples, the conventional water treatment process was efficient enough to remove NPEOs. The removal of NPEOs was perhaps the result of adsorption by coagulants.

The 4-NP removal rate, on the other hand, varied in a range from $62 \%$ to $94 \%$, resulting in a considerably high residual 4$\mathrm{NP}$ concentration in drinking water in July $(0.1-2.7 \mu \mathrm{g} / \mathrm{L})$. It seemed that adsorption only by the coagulant was not sufficient for 4-NP removal. It should be noted that a part of the removed 4-NP would be chloridized to form several halogenated byproducts, which may elicit antagonist action ( $\mathrm{Hu}$ et al. 2002). Considering that the main drinking water sources in Chontqing Area are from the Jialingjiang River and the Changjiang River, advanced treatment processes such as activated carbon adsorption or ozonation (Paune et al. 1998) will be necessary to reduce the potential risk of 4-NP in drinking water. 

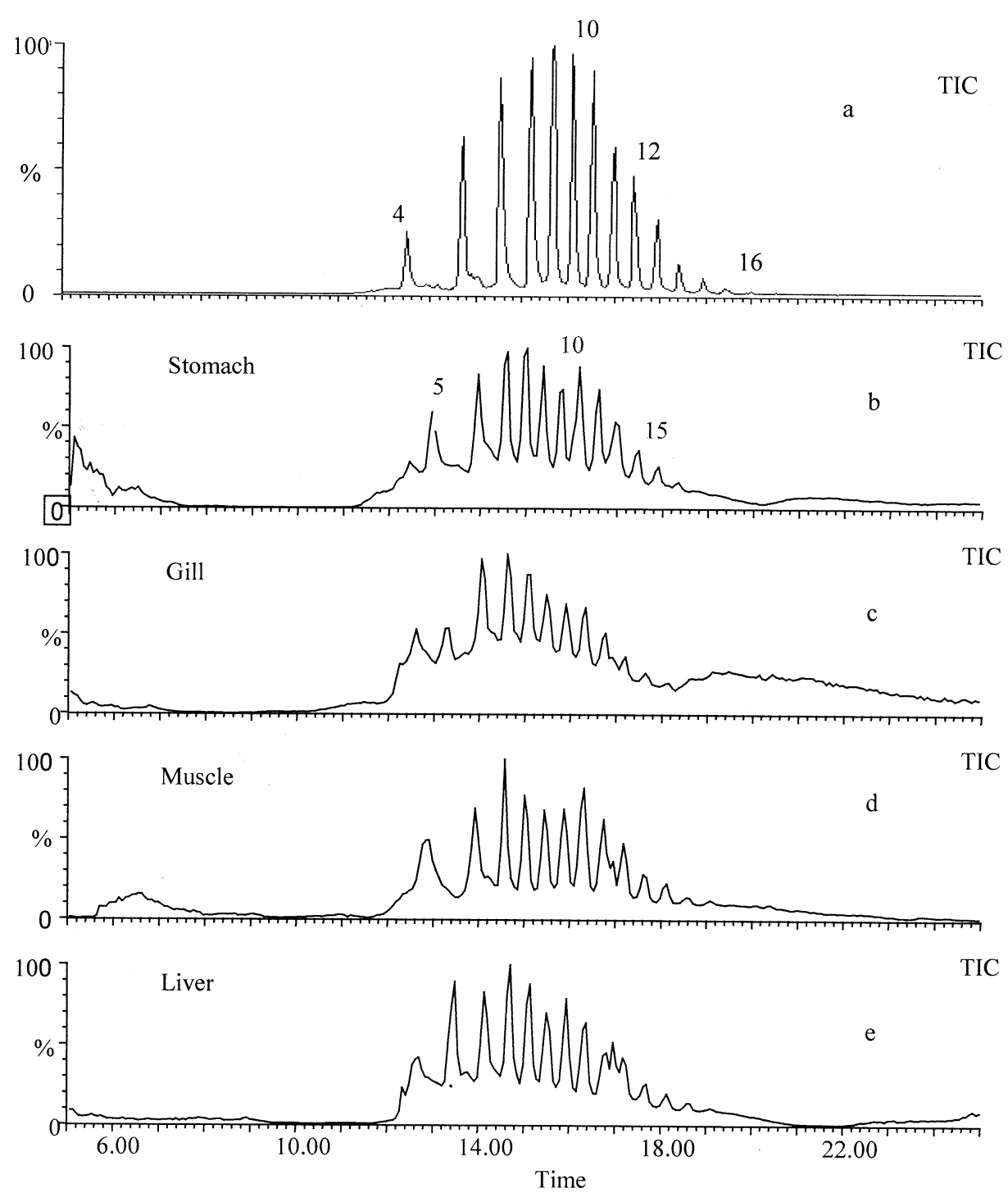

TIC

IC 
Table 2. Concentration of 4-NP and NPEOs in fish tissues taken in December ,2000 $(\mu \mathrm{g} / \mathrm{g})$

\begin{tabular}{lllr}
\hline Type of sample (River) & Data & 4-NP & NPEOs \\
\hline Coreius Guichenoti muscle (Changjiang) & Dec. & 0.02 & 0.8 \\
Coreious Guichenoti gill & & 0.4 & 5.8 \\
Coreius heterodon muscle (Changjaing) & Dec. & 0.08 & 0.5 \\
Coreius heterodon gill & & & \\
Leptobotia elongata muscle (Changjiang) & Dec. & 0.09 & 1.3 \\
Coreius heterodon liver & & 0.8 & 20.2 \\
Coreius heterodon gill & & 0.1 & 2.1 \\
Rhinogobio typus muscle (Jialingjaing) & Dec. & ND & 0.5 \\
Rhinogobio typu gill & & 0.1 & 4.7 \\
Rhinogobio ventralis muscle(Jialingjiang) & Dec. & 0.02 & 0.4 \\
Rhinogobio ventralis liver & & 1.9 & 48.3 \\
Rhinogobio ventralis gil & & 0.2 & 3.5 \\
Rhinogobio ventralis stomach & & 0.2 & 2.2 \\
\hline
\end{tabular}

ND - not deteced, 4-NP, 4-nonylphenol; NPEOs, nonylphenol ethoxylates.

The 4-NP and NPEOs concentration levels in the water samples near sites B and D were used to estimate the bioconcentration factor $(\mathrm{BCF})$, a ratio between the concentration of a chemical in the tissues of an organism and the concentration the chemical in water. Although the value of BCF in our study is not exactly true because of the migration, it can be an indicator of water pollution. The BCF of 4-NP ranged from 1 to 25,6 to 102 , and 80 to 204 in muscles, gills, and livers respectively, showing that 4-NP tends to accumulate in liver tissues. These results of field study were consistent with those reported by Tsuda et al. (2000), where BCF for 4-NP was estimated in the range of 13-408. For NPEOs, the BCF is from 5 to 36,40 to 157 , and 57 to 5100 in muscles, gills, and livers, respectively, indicating that NPEOs are more easily bioconcentrated in fish than 4-NP. As we have determined, the sewage treatment ratio in Chongqing is very low (http:// www.cqpa.gov.cn/lxryzl/3/info-20020611-2.htm), furthermore, there are no sewage treatment plants near the sampling sites because of the existence of the waterworks. Therefore, the levels detected in our study are higher than that found in other countries.

\section{Potential Risk}

As for human health implications, epidemiological studies are not available, and toxicological ones are limited. Therefore, the human health implications associated with these results are difficult to predict. A 90-day oral subchronic toxicity for rats indicated that 4-NP did not cause any effects at $50 \mathrm{mg} / \mathrm{kg}$ bw/ day (Cunny et al. 1997). On the assumption that one person takes in $200 \mathrm{~g}$ river fish tissues and $2 \mathrm{~L}$ drinking water, the maximum of 4-NP was estimated to be $390 \mu \mathrm{g} /$ person/day, or $65 \mu \mathrm{g} / \mathrm{kg}$ bw, which is much lower than that which can elicit subchronic toxicity on laboratory rat (Cunny et al. 1997). Although there is a low risk of 4-NP from the view of human consumption, more attention should be paid to ecological risk because the highest levels of 4-NP and NPEOs ever reported were found in Rhinogobio ventralis liver. It should be noted that 4-NP concentration near the threshold concentration (10 $\mu \mathrm{g} / \mathrm{L}$ ) that affects fish reproduction (Jobling et al. 1996) occurred in the Chanjing River.

Finally, the results obtained in this study filled existing gap in China, and provided useful information for related researchers and policy makers in the world.

Acknowledgments. Financial support from the National Natural Science Foundation of China (49925103, 20307010, and 40021101) is gratefully acknowledged.

\section{References}

Ahel M, Giger W, Koch M (1994) Behaviour of alkylphenol polyethoxylate surfactants in the aquatic environment-I. Occurrence and transformation in sewage treatment. Water Res 28:11311142

Blackburn MA, Waldock MJ (1995) Concentrations of alkylphenols in rivers and estuaries in England and Wales. Water Res 29:16231629

Blackburn MA, Kirby SJ, Waldock MJ (1999) Concentrations of alkyphenol polyethoxylates entering UK estuaries. Marine Pollution Bull 38:109-118

Clark LB, Rosen RT, Hartman TG, Louis JB, Suffet IH, Lippincott RL, Rosen JD (1992) Determination of alkylphenol ethoxylates and their acetic acid derivatives in drinking water by particle beam liquid chromatography mass-spectrometry. Int J Environ Analyt Chem 47:167-180

Cunny HC, Mayes BA, Rosica KA, Trutter JA, Van Miller JP (1997) Subchronic toxicity (90-day) study with para-nonylphenol in rats. Regul Toxicol Pharmacol 26:172-178

Di Corcia A, Costantino A, Crescenzi C, Marinoni E, Samperi R (1998) Characterization of recalcitrant intermediates from biotransformation of the branched alkyl side chain of nonylphenol ethoxylate surfactants. Environ Sci Technol 32:2401-2409

Di Corcia A, Cavallo R, Crescenzi C, Naqzzari M (2000) Occurrence and abundance of dicarboxylated metabolites of nonylphenol polyethoxylate surfacants in treated sewages. Environ Sci Technol 34:3914-3919

Ferrara F, Fabietti F, Delise M, Bocca AP, Funari E (2001) Alkylphenolic compounds in edible molluscs of the Adriatic Sea (Italy). Environ Sci Technol 35:3109-3112

Harries JE, Sheahan D, Osborne JA, Mathiessen P, Neall P, Routledge EJ, Rycroft R, Sumpter JP, Tylor T (1996) A survey of estrogenic activity in United Kingdom inland waters. Environ Toxicol Chem 15:1993-2002

Hu JY, Xie GH, Aizawa T (2002) Products of aqueous chlorination of 4-nonylphenol and their estrogenic activity. Environ Toxicol Chem 21:2034-2039

Huang HZ (1998) Handbook of chemical products: industrial surfactant Chemical Industry Press, Beijing

Jobling S, Sheahan D, Osborne JA, Matthiessen P, Sumpter JP (1996) Inhibition of testicular growth in rainbow trout (Oncorhynchus mykiss) exposed to estrogenic alkylphenolic chemicals. Environ Toxicol Chem 15:194-202

Jonkers N, Knepper TP, Voogt PD (2001) Aerobic biodegradation studies of nonylphenol ethoxylates in river water using liquid chromatography electrospray tandem mass spectrometry. Environ Sci Technol 35:335-340

Kannan K, Keith TL, Nalor CG, Staples A, Snyder SA, Giesy JP (2003) Nonylphenol and nonylphenol ethoxylates in fish, sediment, and water from the Kalamazoo River, Michigan. Arch Environ Contam Toxicol 44:77-82 
Keith TL, Snyder SA, Naylor CG, Staples CA, Summer C, Kannan K, Giesy JP (2001) Identification and quantitation of nonylphenol ethoxylates and nonylphenol in fish tissues from Michigan. Environ Sci Technol 35:10-13

Lye CM, Frid CLJ, Gill ME, Cooper DW, Jones DM (1999) Estrogenic alkylphenols in fish tissues, sediments, and waters from the UK Tyne and Tees estuaries. Environ Sci Technol 33:1009-1014

Maruyama K, Yuan M, Otsuki A (2000) Seasonal changes in ethylene oxide chain length of poly(oxyethylene)alkylphenyl ether nonionic surfactants in three main rivers in Tokyo. Environ Sci Technol 34:343-348

Naylor CG, Williams JB, Varineau PT, Webb DA (1996) In: Proceedings of the 4th World Surfactants Congress, Barcelona, Spain, vol. 4, p 378

Paune F, Caixach J, Espadaler I, Om J, Rivera J (1998) Assessment on the removal of organic chemicals from raw and drinking water at a Llobregat river waterworks plant using GAC. Water Res 32:3313-3324

Rice CP, Schmitz-Afonso I, Loyo-Rosales JE, Link E, Thoma R, Fay L, Altfater D, Camp MJ (2003) Alkylphenol and alkylphenol-ethoxylates in carp, water, and sediment from the Cuyahoga River, Ohio. Environ Sci Technol 37:3747-3754

Servos MR (1999) Review of the aquatic toxicity, estrogenic responses and bioaccumulation of alkylphenols and alkylphenol polyethoxylates. Water Qual Res J Canada 34:123-177

Shao B, Hu JY, Yang M (2002a) Determination of nonylphenol ethoxylates in the aquatic environment by normal phase liquid chromatography-electrospray mass spectrometry. J Chromatogr A 950:167-174

Shao B, Hu JY, Yang M (2002b) A survey of nonylphenol in aquatic environment of Chongqing valley. Acta Scient Circumstant 22:12-16 (in Chinese)

Sharpe RM, Fisher JS, Millar MM, Jobling S, Sumpter JP (1995) Gestational and lactational exposure of rats to xenoestrogens results in reduced testicular size and sperm production. Environ Health Perspect 103:1136-1143

Stachel B, Ehrhorn U, Heemken OP, Lepom P, Reincke H, Sawal G, Theobald N (2003) Xenoestrogens in the River Elbe and its tributaries. Environ Pollution 124:497-507

Thiele B, Gunther K, Schwuger MJ (1997) Alkylphenol ethoxylates: trace analysis and environmental behavior. Chem Rev 97:32473272

Tsuda T, Takino A, Kojima M, Harada H, Muraki K, Tsuji M (2000) 4-Nonylphenol and 4-tert-octylphenol in water and fish from rivers flowing into Lake Biwa. Chemosphere 41:757-762

Uguz C, Iscan M, Ergüven A, Isgor B, Togan I (2003) The bioaccumulation of nonylphenol and its adverse effect on the liver of rainbow trout (onchorynchus mykiss). Environ Res 92:262-270

White R, Jobling S, Hoare SA, Sumpter JP, Parker MG (1994) Environmentally persistent alkylphenolic compounds are estrogenic,. Endocrinology 135:175-182

http://www.cqpa.gov.cn/lxryzl/3/info-20020611-2.htm

http://www.cin.gov.cn/indus/speech/2001072303.htm 